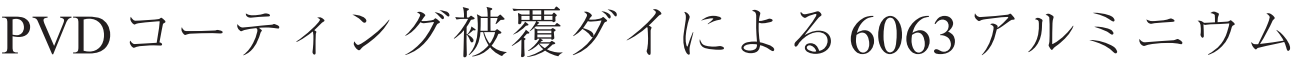 合金熱間押出のピックアップ欠陥の抑制
}

\author{
船塚 達也 ${ }^{1 *} \cdot$ 高辻 則夫 $^{2}$ \\ 堂田 邦明 $^{3} \cdot$ 渡辺 悠太郎 ${ }^{4}$
}

Journal of The Japan Institute of Light Metals, Vol. 70, No. 11 (2020), 510-516

(C) 2020 The Japan Institute of Light Metals

\section{Suppression of pick-up defects in hot extrusion of 6063 aluminum alloy by using PVD coating die}

\author{
Tatsuya FUNAZUKA ${ }^{1 *}$, Norio TAKATSUJI ${ }^{2}$ \\ Kuniaki DOHDA ${ }^{3}$ and Yutaro WATANABE ${ }^{4}$
}

\begin{abstract}
6000 series aluminum alloys are used in a variety of fields including architectural products and automobiles. These products require complex cross-sectional shapes and high productivity. In the forming of products that meet these market requirements, surface defects such as pick-up and tearing occur. In the previous report, we focused on the mechanism of pick-up defects on the extrusion surface. The cause of the pick-up defects was the preferential adhesion of $\mathrm{Mg}$ and $\mathrm{O}$ to the die bearing surface. In this paper, a die coating is applied as a method to suppress the pickup defects. AlCrN, TiAlN, Diamond-like carbon (DLC) were applied and compared to the Nitriding. The number of pick-up in the DLC increased as the stroke progressed, and surface layer delamination of DLC was observed after extrusion. Mg oxide wasn't observed in AlCrN and TiAlN on the bearing surface. And, surface delamination wasn't observed with these coatings. The coatings such as AlCrN and TiAlN to the die bearing surface were effective in suppressing pick-up defects.
\end{abstract}

(Received June 25, 2020 Accepted September 15, 2020)

Keywords: 6063 aluminum alloy; hot extrusion; pick-up; die coating

\section{1. 緒言}

アルミサッシなどに広く使用されている6063アルミニウ ム合金押出製品の多くはポートホールダイを用いて押出した 中空形材である。そして, その断面形状は, 機能性の向上な どを求め，ますます複雑さを増す一方で，表面品質の向上や 低コストの要求も増してきている。しかし, 複雑な断面形状 や生産性を高めた押出条件での押出加工では，押出材表面上 にピックアップと呼ばれる米粒状のむしれ欠陥が不規則に発 生する。このピックアップ久陥を抑制し，押出材の表面品質 の低下を防ぐためには，押出速度の低速化が有効である。

著者らの前報 ${ }^{1)} に て, \quad \mathrm{Al}-\mathrm{Mg}-\mathrm{Si}$ 系合金の熱間押出加工にお けるピックアップ欠陥発生メカニズムの検討を行った。発生 メカニズムとして，熱間押出が進むにつれて押出中のダイの ベアリング面での摩擦およびビレット内部のせん断変形によ る加工発熱が発生する。Trindade ${ }^{2)}$ の報告から $550^{\circ} \mathrm{C}$ の高温
化で工具鋼表面では $\mathrm{Fe}_{2} \mathrm{O}_{3}$ 層が形成される。ビレットである $\mathrm{Al}-\mathrm{Mg}-\mathrm{Si}$ 系合金では, Wefers $ら^{3)}$ 拉よび, 加藤ら ${ }^{4)}$ の報告か ら, $300^{\circ} \mathrm{C}$ 以上の高温下でマグネシウム（以下， Mg) が最表 面へ拡散される。ベアリング部で押出材表面の $\mathrm{Mg}$ とダイ表 面の $\mathrm{Fe}_{2} \mathrm{O}_{3}$ との接触による酸化還元反応によって, ベアリン グ面に $\mathrm{Mg}$ 酸化物が付着する。 $\mathrm{Mg}$ 酸化物によって押出材がむ しられ，離脱することでピックアップ欠陥が発生することを 明らかにした。年の抑制方法として，ベアリング面の酸化の 防止とベアリング面上でのダイと押出材の接触を防ぐ必要が あることを報告した。べアリング面に打けるトライボ特性の 向上がピックアップ欠陥の抑制に有効であると考えられる。 そこで, 本報ではベアリング面の酸化の防止とトライボ特 性の向上を目的として, ベアリング面上へのコーティング処 理を検討する。著者らの解説記事 ${ }^{5), 6}$ に記述した通り, コー ティング処理は冷間加工での適用がほとんどであり, 熱間加 工では板成形などの限られた塑性加工にのみ使用されてい

\footnotetext{
1 富山大学学術研究部工学系（广930-8555 富山県富山市五福 3190） Academic Assembly Faculty of Engineering, University of Toyama（3190 Gofuku, Toyama-shi, Toyama, 930-8555)

2 富山大学学術研究部都市デザイン学系（富山市） Academic Assembly Faculty of Sustainable Design, University of Toyama（Toyama-shi, Toyama）

${ }^{3}$ Department of Mechanical Engineering, Northwestern University, Evanston, IL, USA

${ }^{4}$ YKK AP 株式会社（黒部市） YKK AP Co., Ltd. (Kurobe-shi, Toyama)

* 責任著者E-mail: funazuka@eng.u-toyama.ac.jp
} 
る。押出加工や鍛造加工といった高圧負荷かつ高表面積拡大 を伴う加工の場合, 加工時の摩擦係数の測定が困難であるこ とから，それらをシミュレートした摩擦試験法はほとんど見 られない。加えて，コーティング自体が高温かつ高負荷条件 に耐えられず，その剥離寿命評価も難しい。加えて，深穴や 狭窄部を有する複雑形状金型が対象となる場合には, イオン プレーティングやスパッタリングなどの物理的蒸着法 (PVD 法）では，製膜ができないため，適用は困難とされてきた。 熱間押出加工におけるコーティング適用例については政ら ${ }^{7)}$ は硬質被膜ダイスにおける表面性状に及ぼす影響およびコー ティングの耐摩耗性, 耐酸化性について報告している。しか し，実用に至るまでの知見が得られておらず，実操業で熱間 塑性加工へダイコーティングを適用した事例は非常に少な い。特に，ピックアップ欠陥などの押出材表面に発生する表 面欠陥などに着目した例はない。

ダイコーティング処理がピックアップ欠陥に及ぼす影響を 調査するために，沉用の表面処理である窒化処理に加え， AlCrN, TiAlN, Diamond-like carbon (DLC) の3種類のPVDコー ティングを適用した。 $\mathrm{AlCrN}$ およびTiAlNについて, Kalin $ら^{8)-10)}$ の一連の研究や Birol $~^{11)}$ による摩擦試験の報告より, 熱間押出温度に近い $500^{\circ} \mathrm{C}$ 時の摩擦係数が小さいこと，また 摺動後のダイに付着したアルミニウム合金の表面積が小さい ことが報告されている。DLCでは，耐熱性には優れてはいな いもののアルミニウム合金に対しての摩擦係数が非常に小さ く，耐摩耗性に優れていることが報告されている ${ }^{12), 13) 。 ~}$

本研究では押出荷重, ピックアップ欠陥数, ダイ表面元素 分析などを行い，ダイ表面へのコーティング処理の適用によ るピックアップ抑制効果を明らかにする。

\section{2. 実験方法}

Table 1 に本実験での押出条件を示す。供試材料は, A6063 合金を使用した。本実験で使用したA6063 合金の組成を Table 2 に示す。ビレット形状は旋削加工にて $\phi 42 \times 100 \mathrm{~mm}$ と

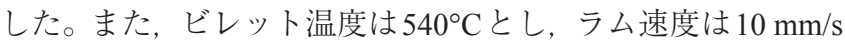
とした。押出比は 28.9 とし, ラムストロークは $90 \mathrm{~mm}$, 潤滑 条件は無潤滑とした。押出用工具はすべて熱間ダイス鋼 （SKD61）を素材とした。熱間押出実験はFig. 1 (a) に示す横 型油圧プレス押出機（最大プレス能力 $2000 \mathrm{kN}$ ）を用いた。

ダイ表面のコーティングがピックアップ欠陥に及ぼす影響

Table 1 Extrusion conditions.

\begin{tabular}{l|c}
\hline \hline Die material & SKD61 \\
Billet material & A6063 \\
Billet shape $[\mathrm{mm}]$ & $\phi 42.0 \times 100$ \\
Extrusion temperature $\left[{ }^{\circ} \mathrm{C}\right]$ & 540 \\
Ram speed $[\mathrm{mm} / \mathrm{s}]$ & 10 \\
Extrusion stroke $[\mathrm{mm}]$ & 90 \\
Extrusion Ratio $[-]$ & 28.9 \\
\hline
\end{tabular}

Table 2 Chemical composition of A6063 alloy [mass\%].

\begin{tabular}{c|c|c|c|c}
\hline \hline Alloy & $\mathrm{Mg}$ & $\mathrm{Si}$ & $\mathrm{Fe}$ & $\mathrm{Al}$ \\
\hline A6063 & 0.48 & 0.49 & 0.15 & $\mathrm{Bal}$. \\
\hline
\end{tabular}

を明らかにするため実験では，Fig. 1(b) に示すような分割ダ イを用いた。ダイ形状はFig. 1(b-1) に示すようにベアリング 長さ $3.0 \mathrm{~mm}$ で, 得られる板材の寸法は幅 $18.6 \mathrm{~mm}$, 厚さ 1.5 mm とした。Fig. 1 (b-2) に分割ダイの概略図を示す。幅 18.6 $\mathrm{mm}$, 高さ $1.5 \mathrm{~mm}$ の凹部が付いたダイを Aとし, 半円となっ ているダイをBとした。Table 3 に供試のコーティングにおけ るコーティング方法, 膜厚, ビッカース硬さ，表面粗さを， Fig. 2 に窒化処理と各種ダイコーティングの粗さ曲線を示す。 各コーティングはベアリング面の表面粗さ $R a$ を $0.1 \mu \mathrm{m}$ 程度 に整えた後にコーティング処理を施した。コーティング後の 表面粗さはFig. 1 (b-2) のBを測定した。TiAlNおよびDLCで 局所的に粗さの高い箇所はドロップレット除去時に発生した 空孔を測定しているものと考えられる。ドロップレットは PVD コーティングの蒸着時にコーティング内部に金属粒子 などが混入することで発生する。それを除去した際にコー

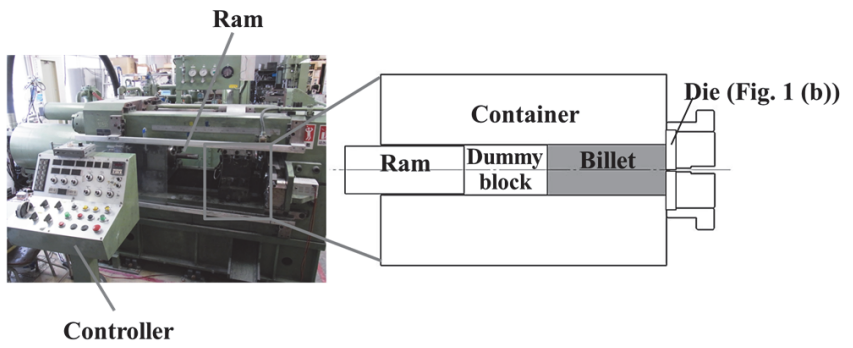

(a) $2000 \mathrm{kN}$ horizontal extrusion press and forming assembly
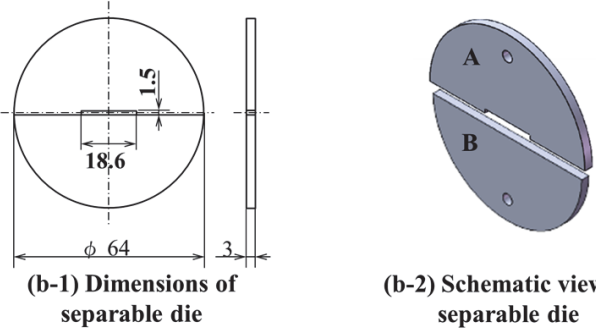

(b-2) Schematic view of separable die

Fig. 1 Experimental apparatus.

Table 3 Properties of the coatings.

\begin{tabular}{c|c|c|c}
\hline \hline $\begin{array}{c}\text { Surface } \\
\text { condition }\end{array}$ & $\begin{array}{c}\text { Thickness } \\
{[\mu \mathrm{m}]}\end{array}$ & $\begin{array}{c}\text { Hardness } \\
{[\mathrm{HV}]}\end{array}$ & $\begin{array}{c}\text { Surface } \\
\text { roughness } \\
\operatorname{Ra}[\mu \mathrm{m}]\end{array}$ \\
\hline Nitriding $^{(1)}$ & 150 & 1100 & 0.122 \\
AlCrN $^{(2)}$ & 3.8 & 3100 & 0.035 \\
$\operatorname{TiAlN}^{(2)}$ & 5.0 & 2800 & 0.074 \\
DLC $^{(3)}$ & 1.0 & 2900 & 0.082 \\
\hline
\end{tabular}

(1) Gas Nitriding, (2) Cathodic Vacuum Arc,

(3) Plasma-enhanced Chemical Vapor Deposition

\begin{tabular}{|c|c|c|}
\hline \multirow{2}{*}{ Die bearing area } & Surface condition & Surface roughness curve \\
\hline & Nitriding & 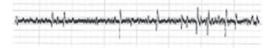 \\
\hline \multirow{3}{*}{$\underset{1 \mathrm{~mm}}{\stackrel{\Xi}{\vdots}}$} & $\mathrm{AlCrN}$ & 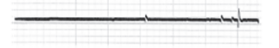 \\
\hline & TiAlN & $\rightarrow+n_{n}$ \\
\hline & DLC & 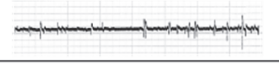 \\
\hline
\end{tabular}

Fig. 2 Surface roughness curve in each surface condition. 
ティング表面に微小な空孔ができるため面粗度の悪化につな がるとされている。

Fig. 3 に熱間押出し実験後の押出材の観察位置と押出材表 面のピックアップ欠陥を示す。押出実験で得られる押出材の 全長はおよそ $2400 \mathrm{~mm}$ の内，押出材先端より $800 \mathrm{~mm}$ ごとに 観察した。また，押出材の形状が幅 $18.6 \mathrm{~mm}$ であることから 左右対称として，ピックアップ欠陥数観察位置は押出方向を 縦として $1.0 \mathrm{~mm}$ ，板材の中心から端部までの幅 $9.3 \mathrm{~mm}$ とし た。押出材表面のピックアップの観察には, 低真空電子顕微 鏡（Miniscope；株式会社日立ハイテク，TM3030）を用いた。 押出材と押残材のミクロ組織観察は光学顕微鏡（Optical microscope, OM ; NIKON, H600L Microscope), 電子線マイク ロアナライザ (Electron probe microanalysis, EPMA ; JEOL, JXA-8230）および同装置の走査型電子顕微鏡（Scanning electron microscopy, SEM）を用いた。押出材表面粗さの測定 に表面粗さ測定器（株式会社小坂研究所, SE-30D）を用いた。 測定距離は $9.3 \mathrm{~mm}$ ，押出方向と垂直方向に測定した。ベアリ ング部および押出材表面の元素分析にはEPMAの波長分散分 光法 (Wavelength-dispersive spectroscopy, WDS）を用いた。ド ロップレットによる空孔部の形状測定には非接触 3 次元形状 測定器（ZYGO Corporation, NewView 7300）を用いた。

\section{3. 実験結果および考察}

\section{1 ピックアップ欠陥および押出材表面に及ぼすダイ コーティングの影響}

図は省略するが，窒化処理， AlCrN，TiAlNおよびDLCの 最大押出荷重はそれぞれ，窒化処理が $527.8 \mathrm{kN}, \mathrm{AlCrN}$ が 496.4 kN，TiAlNが495.4 kN，DLCが 515.0 kN となった。本実 験では，ダイコーティングの適用は押出荷重に影響を及ぼさ ないことがわかった。

Fig. 4 に各種ダイコーティングにおけるピックアップ欠陥 数を示す。窒化処理では最も多く押出材表面にピックアップ 欠陥が発生した。また，押出が進むにつれてピックアップ欠 陥が増加することがわかった。DLCでは，窒化処理に比べて 押出初期ではピックアップの発生が抑制されたが，押出の進 行とともにピックアップ欠陥が増加した。これらに対して, AlCrNおよびTiAlNでは, いずれの地点でも0から2個程度と 窒化処理とDLCに比べてピックアップ欠陥数が少ないこと がわかった。

Fig. 5 (a) に各種ダイコーティングにおける押出材表面粗さ を示す。いずれのコーティング処理でも押出材表面粗さ $R a$ は， $0.080 \sim 0.125 \mu \mathrm{m}$ 程度の非常に滑らかな表面状態であり，

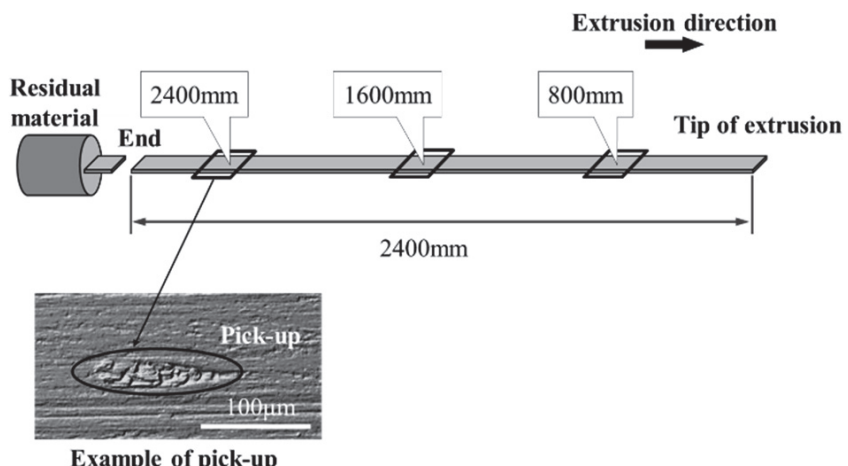

Fig. 3 Surface observation position of extrusion.

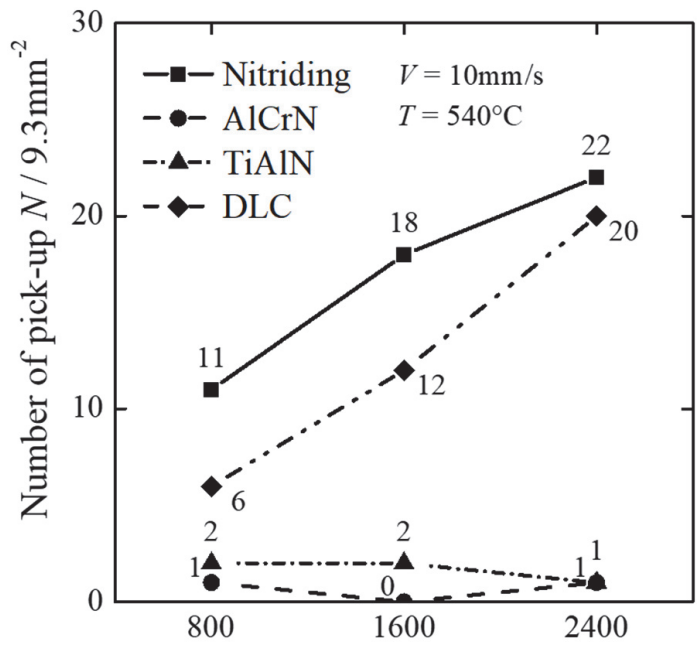

Length of extrusion from tip $L / \mathrm{mm}$

Fig. 4 Number of pick-up in each die coating. (Extrusion temperature $540^{\circ} \mathrm{C}$, Ram speed $V 10 \mathrm{~mm} / \mathrm{s}$ )

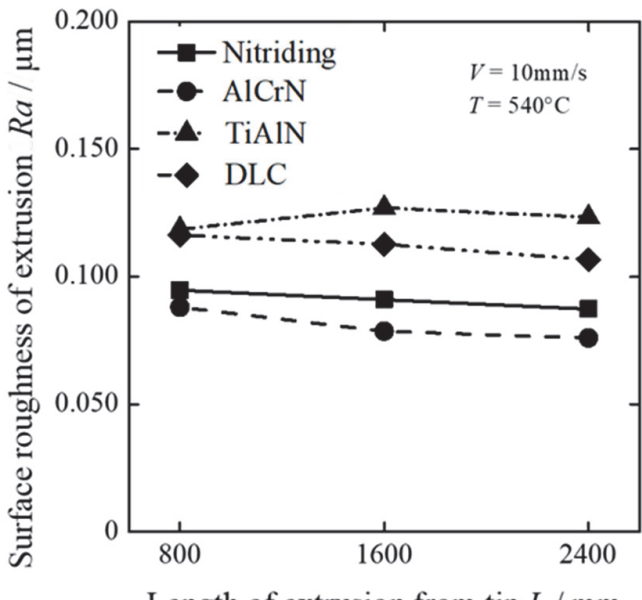

(a) Surface roughness of each length of extrusion from tip

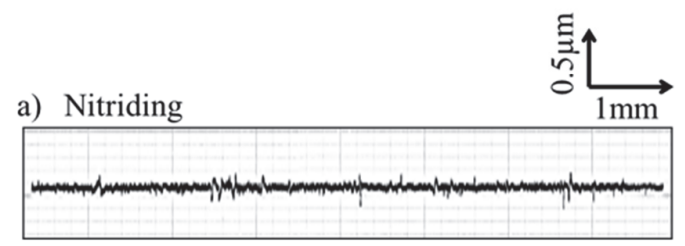

b) $\mathrm{AlCrN}$

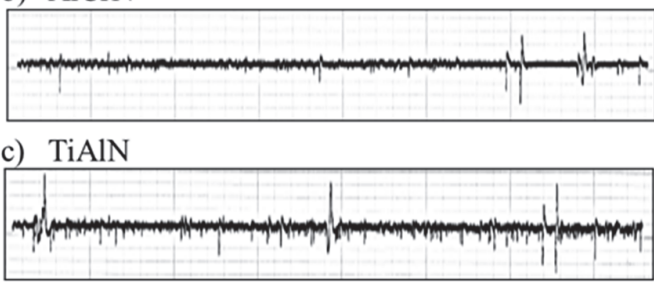

d) DLC

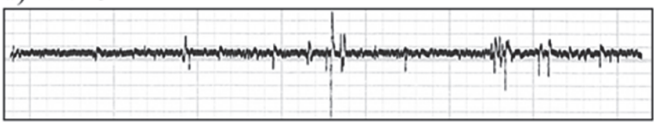

(b) Surface roughness curve of extrusion (Extrusion length $2400 \mathrm{~mm}$ )

Fig. 5 Surface roughness of extrusion in each die coating. 
押出の進行とともに表面状態が悪化することもなかった。 Table 1 に示すダイ表面粗さも $0.035 \sim 0.125 \mu \mathrm{m}$ 程度と非常に 滑らかな表面となっており，押出材も同程度の表面粗さと なった。Fig. 5(b) に押出材先端から $2400 \mathrm{~mm}$ での押出材の表 面粗さ曲線を示す。窒化処理と $\mathrm{AlCrN}$ では表面粗さ曲線に大 きなピークは見られなかった。一方でTiAINとDLCでは表面 粗さ曲線にいくつか粗さの值が高い個所が見られた。Fig. 5 (b) の特に粗さの值が高い個所ではダイラインが見られた。

以上の結果から，ベアリング面に $\mathrm{AlCrN}$ および TiAlNを処 理すると押出材表面のピックアップ欠陥を抑制し， AlCrNで は良好な押出材表面を得ることが出来た。

\section{2 ベアリング面観察および元素分析}

Fig. 6 に各種ダイコーティングにおけるべアリング面外観 のモノクロ図を示す。押出後のベアリング面外観モノクロ図 の黒い部分がダイ表面, 白い部分がアルミニウム合金であ る。Fig. 6 から, 窒化処理 $>$ TiAlN $>$ DLC $>$ AlCrNの順でベアリ ング面上のアルミニウム合金の付着範囲が広いことが見てわ かる。次に押出後のダイ表面の状態を観察するために, アル ミニウム（以下, Al) を溶解 $(20 \% \mathrm{NaOH}$ 水溶液， 30 分間）し た。それぞれの条件のベアリング面観察とEPMAによるカ ラーマップ分析を行い，コーティングの状態および付着物の 元素を観察した。

Fig. 7 に Al 溶解後の各種ダイコーティングのベアリング面 観察結果を示す。観察位置はべアリング中央の出口部（図内 C), ベアリング端の出口部（図内E）の2 ケ所とし, 観察範 囲は $1 \mathrm{~mm}$ 四方とした。それぞれの観察位置で, 窒化処理と $\mathrm{AlCrN}$ の表面ではダイ表面に損傷などは観察されなかった。 TiAlN とDLCの表面ではドロップレット除去時に出来た空孔 が多数見られる。また Fig. 6 の TiAlN と DLCの押出後のベア リング面外観でも点状に堆積したアルミニウム合金が無数に 見られ，この空孔に押出中のアルミニウム合金が堆積するこ とでベアリング面へのアルミニウム合金の凝着面積が広く

Extrusion direction

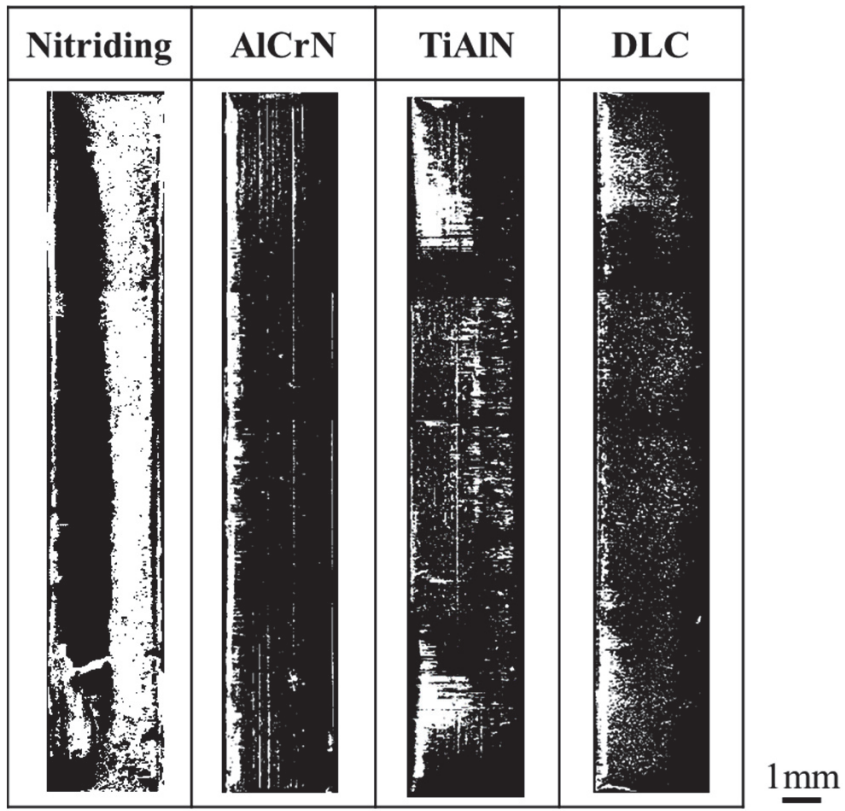

Fig. 6 Die bearing surface after extrusion in each die coating. (Extrusion length $2400 \mathrm{~mm}$ )
なったと考えられる。一方で, Fig. 4から TiAlNでの押出材表 面にピックアップ欠陥は確認されていない。TiAlN表面にあ るドロップレットはダイ表面へのアルミニウム合金付着量の 増加につながるが，ピックアップ欠陥に影響を及ぼさないと 考えられる。AlCrNでは, Table 3からコーティングの算術平 均粗さRaが特に低いこと, Fig. 6 から点状のアルミニウム合 金の堆積が少ないことから，TiAlNやDLCほど粗さの増加が 見られなかったと考えられる。

Fig. 8 に各種ダイコーティングにおけるべアリング面元素 分析結果を示す。Fig. 8(a) より, 窒化処理の分析結果から, 前報同様に, $\mathrm{Mg}$ の反応が強く, ビレット内の $\mathrm{Mg}$ が熱間のダ イ表面で形成される $\mathrm{Fe}_{2} \mathrm{O}_{3}$ と優先的にベアリング面に付着し たと考えられる ${ }^{1)}$ 。また, $\mathrm{Mg}$ と同じ範囲で酸素（以下，O） の反応も強いため, 堆積物は $\mathrm{MgO}$ と考えられる。Fig. 8(b)よ り, $\mathrm{AlCrN}$ の分析結果から $\mathrm{Mg}$ のベアリング面への付着は確 認されなかった。ピックアップ欠陥発生原因であるべアリン グ面への $\mathrm{Mg}$ 酸化物の付着を防止したことで，ピックアップ 欠陥を抑制することができたと考えられる。また， $\mathrm{AlCrN} に$ 含有している $\mathrm{Al}$, クロム (以下, $\mathrm{Cr}$ ), 窒素 (以下, $\mathrm{N}$ ) の反 応が高いこと，またダイの主成分である鉄（以下， Fe）の反 応がないことからコーティングの剥離は観察されなかった。 局所的な付着についてはドロップレットに $\mathrm{Al}$ が堆積したも のと考えられる。Fig. 8(c)より, TiAlNの分析結果から AlCrN と同様に, $\mathrm{Mg}$ のベアリング面への付着は確認されず, コー ティングの剥離についても観察されなかった。Fig. 8(d) よ り，ピックアップ久陥が発生したDLCでも $\mathrm{Mg}$ のベアリング 面への付着は確認できなかった。また，ダイの主成分である $\mathrm{Fe}$ の反応が強いことから熱間押出中にコーティングは損傷 および劣化したと考えられる。一方で，DLCの下地処理とし

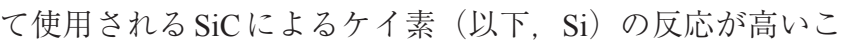
とから, $\mathrm{Mg}$ とダイ表面の $\mathrm{Fe}$ は直接的に接触していないため, $\mathrm{Mg}$ のベアリング面への付着は確認できなかったと考えられ る。また，DLCは本実験の押出温度のような高温条件で摩擦 係数が増大し, 被加工材の凝着量の増加および, コーティン
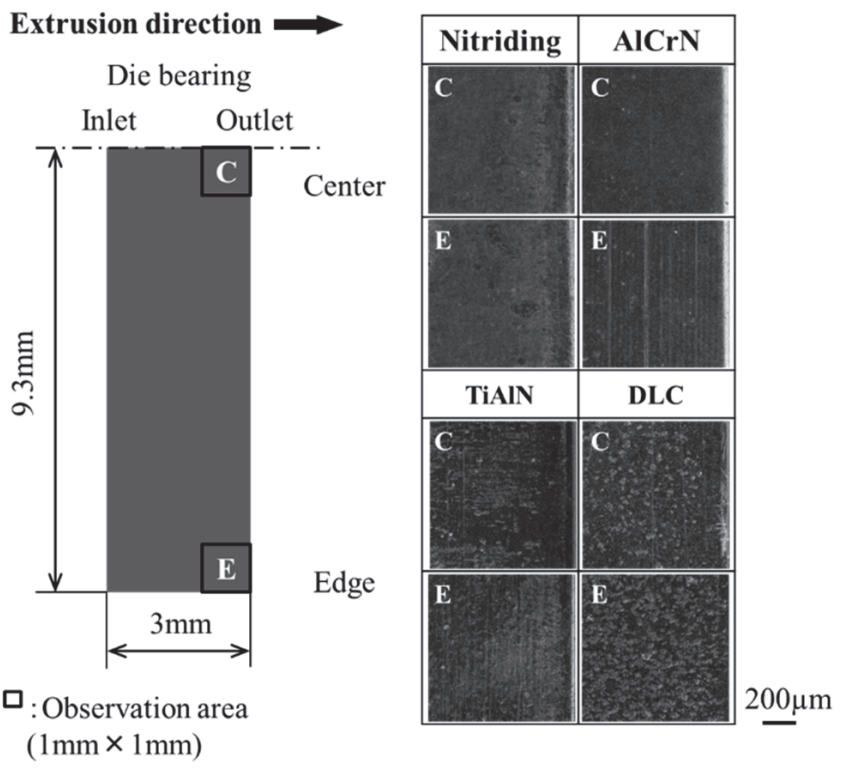

Fig. 7 Die bearing surface after $\mathrm{Al}$ dissolution in each die coating. (Extrusion length $2400 \mathrm{~mm}$ ) 
(a) Nitriding

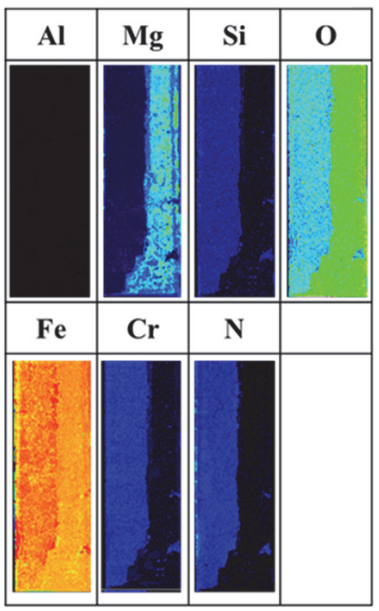

(c) TiAlN

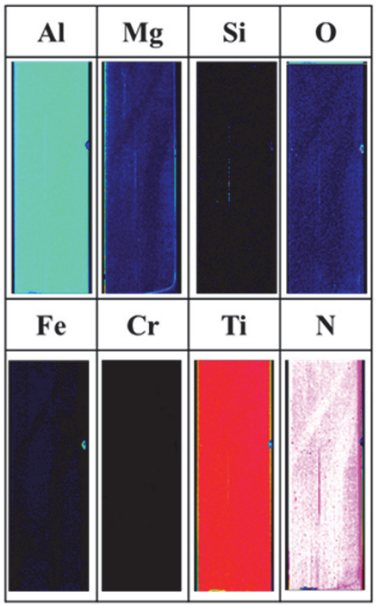

Extrusion direction $\longrightarrow$

(b) $\mathrm{AlCrN}$

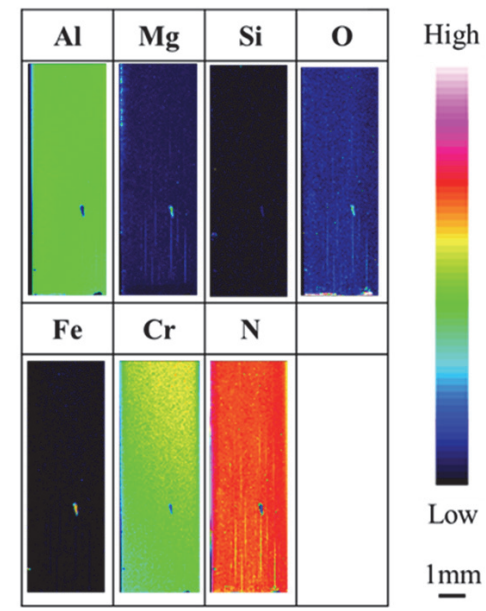

(d) DLC

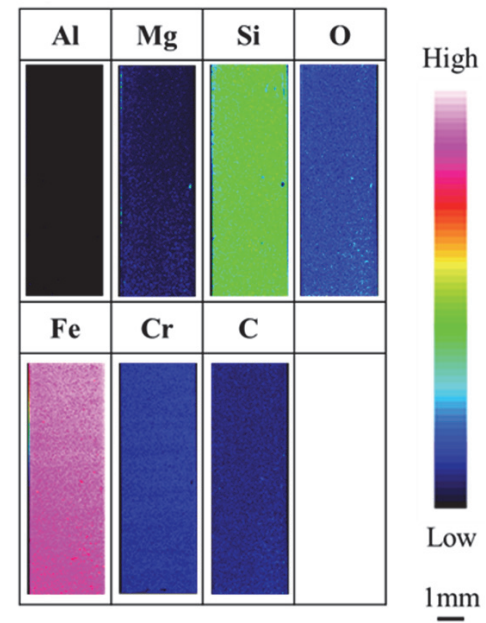

Fig. 8 Die bearing surface color map analysis results in each die coating. (Extrusion length $2400 \mathrm{~mm}$ )

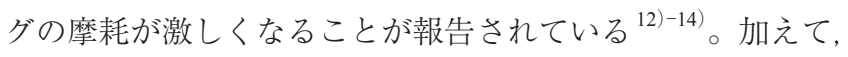
$350 \sim 450^{\circ} \mathrm{C}$ の温度範囲でコーティング自体が酸化し, 劣化す ることが報告されている ${ }^{15)}$ 。Fig. 8(d) でも O の反応があり, ダイ表面のDLCが酸化したと考えられる。

Fig. 8(d）のDLCでは, 酸化したDLC表面を確認できたが, $\mathrm{Mg}$ の付着は確認できなかった。Fig. 6 およびFig. 7 から DLC 表面はドロップレットによる空孔部が無数に存在することが わかっており，押出後には空孔部に点状のアルミニウム合金 の堆積が観察された。Fig.9にAl溶解後のDLC表面における ドロップレットによる空孔部の SEM 像とその形状, Mg, O, Cの元素分析結果を示す。空孔部の形状は幅がそれぞれ 30 $\mu \mathrm{m}$ 程度, 深さ $1.0 \mu \mathrm{m}$ 程度であった。また, 空孔部に $\mathrm{Mg}$ と $\mathrm{O}$ の強い反応が観察された。DLCの主成分である $\mathrm{C}$ も観察され た。従って, 押出中にドロップレットによる空孔部に $\mathrm{Mg}$ を 含んだアルミニウム合金が堆積したと考えられる。また，高 温条件下でDLC 自体が酸化することから, 押出が進むにつれ て，空孔部に堆積したアルミニウム合金の $\mathrm{Mg}$ と酸化した DLC 表面で Mg酸化物を形成したと考えられる。

以上の結果から，ベアリング表面の $\mathrm{Mg}$ を含む合金元素の 付着がピックアップ欠陷発生の原因となると考えられる。 Fig. 10 にダイコーティングの有無での押出中のベアリング部
の模式図を示す。窒化処理の場合, 熱間押出中にビレットと ダイは直接接触する。著者らの過去の研究から, ビレットと ダイ界面のせん断変形によって発生する加工発熱により, ベ アリング部では最大 $100^{\circ} \mathrm{C}$ 程度の温度上昇が発生することを 報告している ${ }^{16)}$ 。Fig. 10(a-1) に示すように押出中の加工発 熱によって, ダイ表面で局所的に $\mathrm{Fe}_{2} \mathrm{O}_{3}$ が形成される ${ }^{2)}$ 。押出 材最表面に拡散された $\mathrm{Mg}$ との接触による酸化還元反応に よって, ベアリング面に Mg 酸化物が付着する ${ }^{3), 4)}$ 。Fig. 10 （a-2）に示すように加工発熱によって酸化還元反応が活発に なり, ベアリング面に付着する $\mathrm{Mg}$ 酸化物が増加すると考え られる。熱間押出が進むにつれて, ベアリング面上に凝着し た $\mathrm{Mg}$ 酸化物によって押出材がむしられ, 離脱することで ピックアップ欠陥が発生したと考えられる。一方で, ベアリ ング部にAlCrNまたはTiAlNを施すことで, Fig. 10(b-1) に示 すようにビレットとダイ間にコーティング膜が存在する。こ れにより, ダイ表面と押出材最表面の直接的な接触が防がれ ると考えられる。同時に, 大気中の $\mathrm{O}$ を起源とする $\mathrm{Fe}_{2} \mathrm{O}_{3}$ 層 の形成によるダイ表面の酸化を抑制したと考えられる。特 に, AlCrNや TiAlNなどの PVDコーティングはKalin ${ }^{8)-10)}$, Birol ${ }^{11)}$ による摩擦試験から, 熱間押出温度に近い $500^{\circ} \mathrm{C}$ 時 の摩擦係数が小さいこと, $\mathrm{Al}$ の凝着量が少ないことが報告さ 


\section{Extrusion direction}

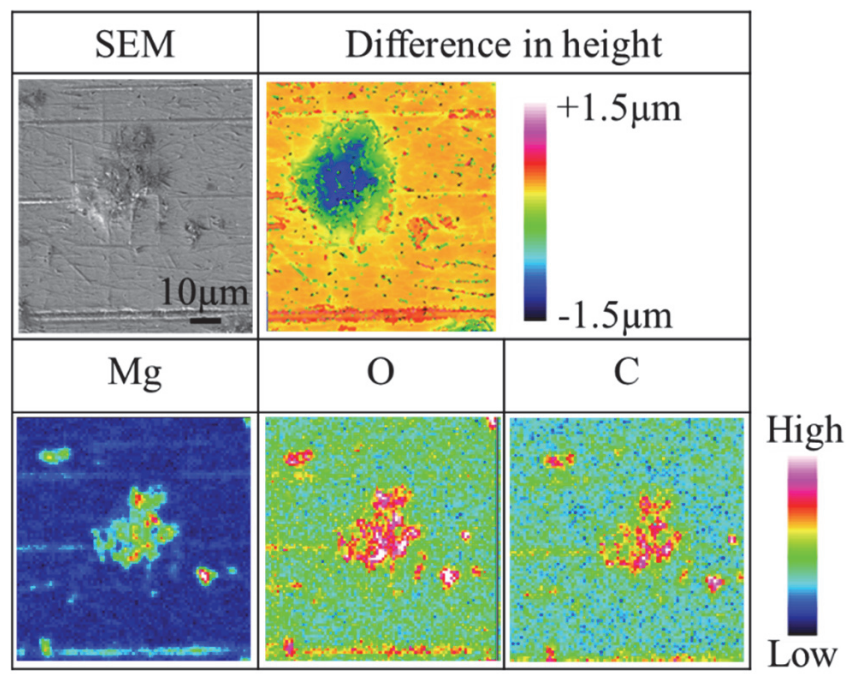

Fig. 9 SEM image, difference in height and color map analysis results of droplets in DLC. (Extrusion length 2400 $\mathrm{mm})$

れている。そのため, ベアリング面への $\mathrm{Mg}$ 酸化物の付着も 少なくなったと考えられる。一方で，DLCでは高温下での摩 擦特性や耐摩耗が低いこと, DLC 自体が酸化し，劣化を起こ すことが報告されている ${ }^{12)-15)}$ 。Fig. 10（b-2）に示すように熱 間押出が進むにつれて, 高温条件下で酸化したDLC表面のド ロップレットによる空孔内部に， $\mathrm{Mg}$ を含んだアルミニウム 合金が堆積することで Mg酸化物が形成される。Mg酸化物が 押出材表面をむしることでピックアップ欠陥が増加したと考 えられる。

\section{3 連続押出実験によるコーティングの性能評価}

押出材先端からの長さ $2.4 \mathrm{~m}$ までは $\mathrm{AlCrN}$ と TiAlNではピッ クアップ欠陥はほとんど発生しなかった。実操業では 1 回の 押出でおよそ $50 \mathrm{~m}$ の押出材に成形する。そこで本項では $\mathrm{AlCrN}$ と TiAlNの有効性をさらに明らかとするために，押出 材先端からの長さ $50 \mathrm{~m}$ までの熱間押出実験を行った。目標と なる長さまでビレットを連続で継ぎ足し，押出を行った。押 出材先端からの長さ $50 \mathrm{~m}$ での TiAlN と AlCrNのピックアップ 欠陥数を測定したが，どちらもピックアップ欠陥は観察され なかった。また，押出材先端からの長さ $10 \mathrm{~m}, 20 \mathrm{~m}, 30 \mathrm{~m}$, $40 \mathrm{~m}, 50 \mathrm{~m}$ 地点での押出材表面粗さを調査した結果，TiAlN ではどの地点でも算術平均粗さで $0.10 \mu \mathrm{m}$ 程度となり, $\mathrm{AlCrN}$ はどの地点でも算術平均粗さで $0.06 \mu \mathrm{m}$ 程度となった。どち らのコーティングでもピックアップ欠陥は確認されず，押出 材表面の粗さに大きな変化は観察されなかった。

Fig. 11 (a) にAlCrN, Fig. 11 (b) にTiAlNの押出材先端から の長さ $2.4 \mathrm{~m}$ と $50 \mathrm{~m}$ における押出後のベアリング部における EPMAによるカラーマップ元素分析を行った結果を示す。べ アリング表面の $\mathrm{Al}$ は $20 \% \mathrm{NaOH}$ 水溶液に 30 分間漬けることで 溶解させた。観察箇所はFig. 8 と同じ箇所を分析した。分析 元素はコーティングの成分である $\mathrm{Al}, \mathrm{Cr}$ ，チタン（以下， $\mathrm{Ti}$ ) およびピックアップ欠陥の発生に影響を与える $\mathrm{Mg}$ と $\mathrm{O}$, 鋼 材の主元素である Feを分析した結果を示す。分析結果の比較 から， AlCrNと TiAlNのどちらのダイコーティングでも押出 が進むにつれて $\mathrm{Mg}$ の付着が確認できた。一方で，Oの付着は
Extrusion direction

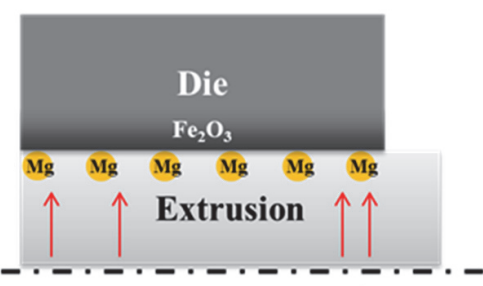

(a-1) Without die coating ( $\mathrm{Mg}$ and $\mathrm{Fe}_{2} \mathrm{O}_{3}$ during extrusion)

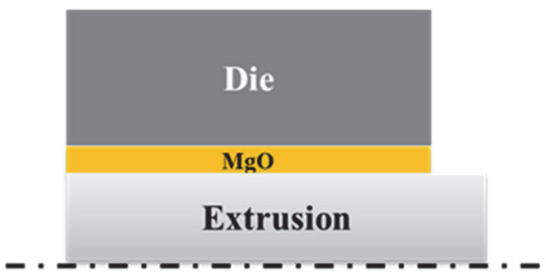

(a-2) Without die coating (Nitriding)

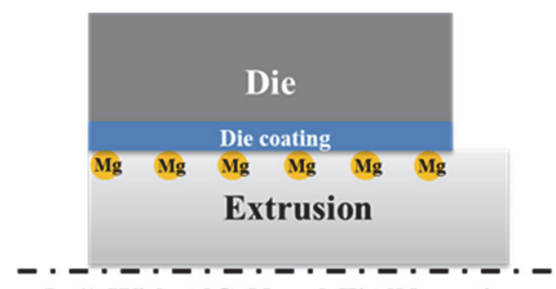

(b-1) With AlCrN and TiAlN coating

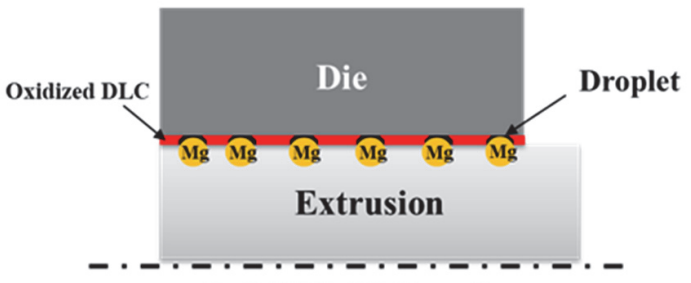

(b-2) With DLC coating

Fig. 10 Schematic diagram of die bearing during hot extrusion.

確認できず, 押出材先端からの長さ $50 \mathrm{~m}$ までの押出で $\mathrm{Mg}$ 酸 化物は生成されなかった。Fig. 8 にて示したように, ビレット 側の $\mathrm{Mg}$ とダイ側の $\mathrm{Fe}_{2} \mathrm{O}_{3}$ による酸化還元反応によって $\mathrm{MgO}$ が生成されることがピックアップ欠陥の発生につながるとこ ろ, ベアリング部にコーティングを施すことで, 酸化還元反 応を阻害し, $\mathrm{MgO}$ の生成を防いだことでピックアップ欠陥を 抑制できたと考えられる。また，AlCrN，TiAlNのどちらにも 含有している $\mathrm{Al}$ の反応が低下した。 $\mathrm{AlCrN}$ については $\mathrm{Cr}$ の反 応が強くなり, TiAlNはTiの反応も低下した。最表面の $\mathrm{Al}$ 含むコーティング層が摩耗したことがわかる。また，押出材 先端からの長さ $50 \mathrm{~m}$ 地点の分析結果ではそれぞれのコー ティングに含有している成分元素の欠落部分が見られないこ と，また，どちらのコーティングでもダイの主成分である Fe の反応が見られなかったことからコーティングの剥離は見ら れなかった。

以上の結果から, TiAlN と AlCrNのいずれのダイコーティ ングも本実験条件下ではピックアップ欠陷発生低減に有用で あると考えられ，押出材先端からの長さを $50 \mathrm{~m}$ まで増加させ てもコーティングの剥離は発生しなかった。 
(a) $\mathrm{AlCrN}$

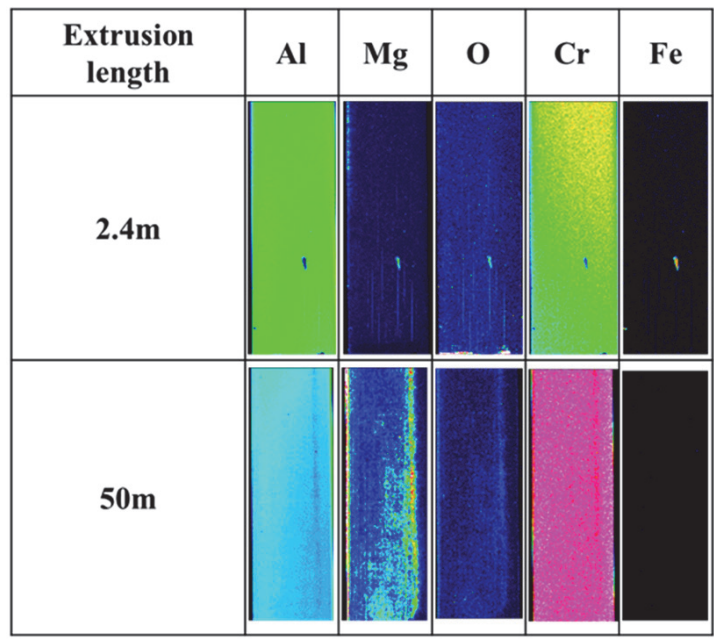

(b) TiAlN

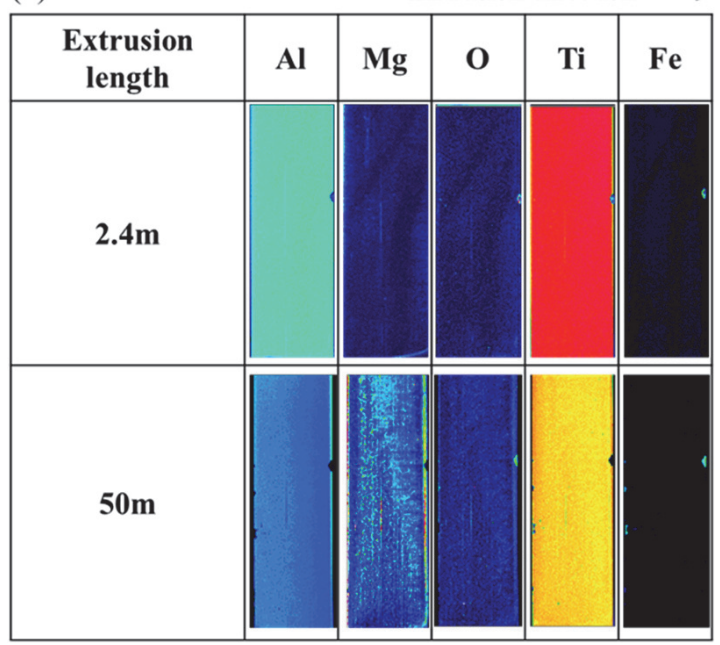

High

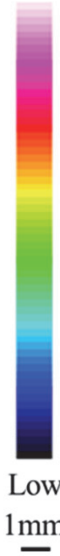

High

Fig. 11 Color map analysis of die surface after A1 dissolution at extrusion length of $2.4 \mathrm{~m}$ and $50 \mathrm{~m}$.

\section{4. 結言}

本報では A6063 合金の熱間押出加工におけるピックアップ 欠陥の抑制方法の検討としてベアリング部にダイコーティン グを施した。ダイを分割することで，ベアリング部にPVD コーティングを製膜することが可能となった。以下に明らか となった知見を示す。

(1) 押出材先端から $2400 \mathrm{~mm}$ までの実験では, $800 \mathrm{~mm}$, $1600 \mathrm{~mm}, 2400 \mathrm{~mm}$ のいずれの地点でも AlCrNおよびTiAlNの ピックアップ欠陥数は, 0 から 2 個程度と窒化処理と DLCに 比べて少なかった。
（2）窒化処理のベアリング面では $\mathrm{Mg}$ と $\mathrm{O}$ の付着が確認さ れた。一方で，AlCrNおよびTiAlNでは $\mathrm{Mg}$ とOの付着が見ら れなかった。DLCでは $\mathrm{Mg}$ の付着は確認されなかったが，Oが 確認され, 酸化によるコーティングの劣化およびFeとDLCの 下地処理の $\mathrm{Si}$ の反応も確認されたため, コーティングの損傷 が生じた。

(3) $\mathrm{AlCrN}$ およびTiAlNでは, 長さ $2.4 \mathrm{~m}$ の押出では数個程 度のピックアップ欠陥が観察されたものの, 長さ $50 \mathrm{~m}$ の連続 押出実験ではピックアップ欠陥は観察されなかった。

\section{謝 辞}

本研究遂行に当たり，実験用のビレットを提供いただいた YKK AP 株式会社に感謝申し上げます。また，コーティング についてご助言いただき, 分割ダイへの被膜にご協力いただ いたトーヨーエイテック株式会社の岡本圭司様に感謝申し上 げます。

\section{参 考 文 献}

1) 船塚達也, 高辻則夫, 土屋大樹, 小田省吾：軽金属, 70 (2020), 415-421, doi.org/10.2464/jilm.70.415.

2) V. B. Trindade, R. Borin, B. Z. Hanjari, S. Yang, U. Krupp, H. J. Christ: Mat. Res., 8 (2005), 365-369, doi.org/10.1590/S151614392005000400002 .

3) K. Wefers: Aluminium, 57 (1981), 722-726.

4) 加藤 豊, 塚本建次, 礒山永三, 内山利光, 成島勝也, 石丸 肇：軽金属, 35 (1985)，228-233， doi.org/10.2464/jilm.35.228.

5) 堂田邦明, N. Mahayotsanun：塑性と加工, 54 (2013), 575-580, doi.org/10.9773/sosei.54.575.

6) K. Dohda, C. Boher, F. Rezai-Aria and N. Mahayotsanun: Friction, 3 (2015), 1-27, DOI 10.1007/s40544-015-0077-3.

7) 政 誠一, 松岡信一, 矢後俊郎：軽金属, 54 (2004), 318-322, doi.org/10.2464/jilm.54.318.

8) J. Jerina and M. Kalin: Wear, 319 (2014), 234-244, doi.org/10.1016/ j.wear.2014.07.021

9) J. Jerina and M. Kalin: Wear, 340 (2015), 82-89, doi.org/10.1016/ j.wear.2015.07.005.

10) M. Kalin and J. Jerina: Wear, 330 (2015), 371-379, doi.org/10.1016/ j.wear.2015.01.007.

11) Y. Birol: Tribol. Int., 57 (2013), 101-106, doi.org/10.1016/ j.triboint.2012.07.023.

12) A. A. Gharam, M. J. Lukitsch, P. M. Balogh, N. Irish and A. T. Alpas: Surf. Coat. Technol., 206 (2011), 1905-1912, doi.org/10.1016/j. surfcoat.2011.08.002.

13) A. Banerji, S. Bhowmick and A. T. Alpas: Surf. Coat. Technol., 241 (2014), 93-104, doi.org/10.1016/j.surfcoat.2013.10.075.

14) S. Bhowmick, M. Lou, M. Z. U. Khan, A. Banerji and A. T. Alpas: Surf. Coat. Technol., 332 (2017), 399-407, doi.org/10.1016/j. surfcoat.2017.06.093.

15) D. Y. Wang, C. L. Chang and W. Y. Ho: Surf. Coat. Technol., 120 (1999), 138-144, doi.org/10.1016/S0257-8972 (99) 00350-3.

16) 谷村将吾, 竹下晴久, 鈴木智典, 福増秀彰, 高辻則夫, 沖田真 吾：軽金属学会第131 回秋期大会講演概要, (2016), 91-92. 